\title{
Dynamics of dissolved inorganic nitrogen in bioturbated littoral surface sediments at a selected tourist destination of Northern Coastal Bay of Bengal, India: An ecologically significant case study
}

\section{Abhishek Mukherjee*, Sabyasachi Chakraborty, Subhajit Das and Tarun Kumar De}

Department of Marine Science. Ballygunge Science College. University of Calcutta. 35 Ballygunge Circular Road. Kolkata - 700019. West Bengal. India. *Email: abmsws@gmail.com.

\begin{abstract}
A case study was undertaken to observe the variations in the concentrations of the dissolved inorganic nitrogen species in the surface sediments of the littoral compartments at Bakkhali and Frasergunj situated within the single coastal stretch at the southernmost tip of West Bengal, India. Effects, if any, of the presence or absence of bioturbations on the variability of the dissolved nitrate-nitrogen, nitrite-nitrogen, ammonia-nitrogen, total dissolved nitrogen and the cumulative concentration of former three variables in the beach surface sediments were also noted. On site nitrite-nitrogen was found in alternate fluctuating patterns throughout the beach zonations with gradual lowering and peaking within each zone. An evidently prominent fact was the independence of dissolved inorganic nitrogen species from bioturbatory influences in the surface sediments of wave exposed littoral environments at the study sites. That effect might become significant in a vertical profile but from the data procured it can be stated that inorganic nitrogen species concentrations in surface beach sediments are not entirely perturbed by bioturbations and are governed by many other environmental parameters. A Pearson correlation performed on the normalized data sets revealed that there existed a fairly significant correlation in between the both the beach sediments with $r$-values ranging from -0.97 to +0.99 among the five variables considered at 95\% confidence level. ANOVA Single factor yielded values in support of the rejection of the null hypothesis.
\end{abstract}

Keywords: Bakkhali; Frasergunj; Littoral zone; Stoichiometry; Inorganic nitrogen; Bay of Bengal.

\section{Introduction}

Oxidation of various organic
compounds trapped within the
Received

September 4, 2018

Accepted

November 23, 2018

Released

December 31, 2018

Full Text Article

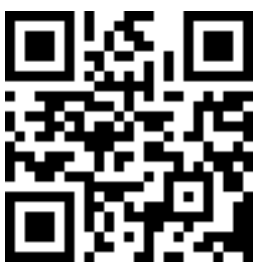

ORCID

(1) 0000-0001-6690-5193

Abhishek Mukherjee

(1) 0000-0001-9691-4314

Sabyasachi

Chakraborty

(1) 0000-0002-7824-6962

Subhajit Das

(1) 0000-0003-2733-7116

Tarun Kumar De

sediments of aquatic ecosystems, especially those of marine and estuarine ecosystem by microbial communities is one of the most important processes of regeneration of nutrients on which the 
benthic and planktonic primary producers rely heavily and thus ensuring the functional stability of the ecosystem (Carpenter and Capone, 1983; Blackburn and Sørensen, 1988; Herbert and Nedwell, 1990; Sloth et al., 1995) and along with carbon, one the most significant elemental nutrients to govern primary production is nitrogen (Dugdale and Goering, 1967; Hecky and Kilham, 1988; Gilbert, 1988) and various stages of the nitrogen cycle are influenced by the availability of reactive carbon sources (Paerl et al., 1987; Smith and Hollibraugh, 1988; Caffrey et al., 1993). Jørgensen and Revsbech (1989) and Lomstein and Blackburn (1992) stated that land ocean boundaries at the coastal areas of estuarine ecosystems, lagoons or oceans are characterized by the lack of atmospheric pressure in terms of volume of water over a certain substrate area and here the biotic transformations of elements are mostly microbe dependent. Rate of conversion of organic nitrogen to its inorganic form through microbial interferences in coastal environments serve as one of the most potential triggering factors of primary productivity as nitrogen is most often cited as the limiting nutrient in marine environments (Dugdale and Goering, 1967; La Roche, 1983; Klump and Martens, 1983; Howarth et al., 1988; Bebout et al., 1994). According to Herbert (1999), the driving force for benthic nitrogen cycling is the degradation of organic matter deposited at the sediment surface or excreted by the roots and rhizomes of rooted macrophytes (Hines et al., 1989; Jensen et al., 1990; Lohse et al., 1993).

There have been many studies performed in the past, for example the likes of works done by Goldhaber et al. (1977) or Caffrey et al. (1993), that have reported the influence of fluvial deposits, trans-sediment transport, lower atmosphere-upper hydrosphere interactions or presence/absence of bioturbation on the concentrations of reactive inorganic nitrogen species among which ammonium and nitrate nitrogen serve to be more influential as nutrients to primary producers in coastal aquatic ecosystems that fall well within the euphotic depth. Works by Blackburn and Henriksen (1983) and Jensen et al. (1990) have focused exclusively on the exchange of nutrients across the benthic sector in aquatic ecosystems and according to them the study of benthic nutrient regeneration and exhaustion in effect demonstrate the rate of oxidation and reduction of nitrogen along the nitrogen cycle through processes like ammonification, nitrification and denitrification, thus depicting the entrapment and emancipation of elemental nitrogen. A highly humic or fulvic benthic environment is a likely product of fluvial or lacustrine inputs laden with suspended particulate matter and the presence of flocculants trigger the sedimentation and the organic matter deposited in such ecosystems is rapidly degraded through intimately linked processes of mineralisation, decomposition and maturation. The degradative activities of the decomposer communities on the organic sediments render the environment oxygen depleted because of their oxygen dependent respiration and generally call for electron acceptors other than oxygen, e.g. $\mathrm{CO}_{2}$, $\mathrm{NO}_{3}, \mathrm{SO}_{4}, \mathrm{Mn}$, oxides of Fe etc (Sørensen et al., 1979; Kerner, 1993) in action. The benthic meiofauna and infauna both play significant roles in processing that portion of the organic load which are pushed down at a rather brisk pace by the overlying sediment layers and otherwise would have been difficult for the heterotrophs to cope with on their own. The sediment surface heterotrophic decomposers work in tandem with the benthic organisms within the sediment layers to regulate the release and regeneration of inorganic nitrogen and/or nitrogenous compounds serving as nutrients. The gradual depletion in the alternative electron acceptors by the sediment microflora results in the formation of clearly demarcated 
biogeochemical strata except where the continuity of these zonations is severed by the bioturbatory features (Aller, 1980).

In order to gain an understanding of the factors regulating nitrogen cycling in coastal marine sediments there is a need to understand how the individual, microbially mediated processes that make up the nitrogen cycle are controlled. The present study was performed on the tidal flats of Bakkhali and Frasergunj, situated on the northern coastal Bay of Bengal and is the first of its kind in terms of investigation of the changes in nitrogen species viz. nitratenitrogen, nitrite-nitrogen and ammonia within the first $5 \mathrm{~cm}$ of sediment from the supralittoral to the sublittoral zone, following a slope from the farthest to the nearest point of the land-sea boundary. The outcome of this study is of immense importance and should contribute to the existing knowledge pool on nitrogen cycling.

The study was governed by the following hypothetical objectives: 1 . Observation of the variation in concentrations of inorganic nitrogen species, 2. Understanding the distribution patterns of inorganic nitrogenous compounds in beach surface sediments, 3. Demarcation of beach zonations with highest and lowest concentrations of inorganic nitrogen species, 4. Establishment of interrelationship, if any, between the same and 5. Expansion of knowledge regarding tropical coastal ecosystems/ ecology by obtaining information from the present study which can be used as references in future.

\section{Material and methods}

\section{Study area}

The Sunderban ecoclimatic region has a physiologically dry saline soil. The edaphic characteristics of the region can be silty, sandy or clayey. Sandy sediment layers are generally encountered near the beach tidal flats extending inwards with the aid of sand dunes and tidal creeks. These are coarser and porous and are not suitable for accumulation of organic carbon which ultimately forms the fertile surface layer. That is the characteristic of forest or mudflat sediments with visibly higher diversity of flora and fauna. Although the marine influence brought about by the high tides render the surface layers to be alkaline $(\mathrm{pH}>8.0)$, predominantly it varies from being acidic to neutral $(\mathrm{pH}$ 5.0-7.3).

The subsurface layers are almost always acidic due to the actions of the anaerobic bacteria and accumulation of litter which ultimately get converted into humic and tannic acids. Another very intriguing feature of the mangrove ecosystem and the beach is the presence of varying degrees of bioturbation which greatly affects the physicochemical nature of this ecosystem, mostly in an ameliorative manner but at times also detrimental (Mukherjee et al., 2016).

The sampling stations were selected based on their physico-chemical parameters mainly focusing on anthropogenically disturbed marine and coastal ecosystems. The selection of stations (Figure 1) was based on the pretext of observing the responses of the biotic communities which are constantly influenced by the ever changing stoichiometry of the ambient media. The following is a short description of the sampling stations:

Bakkhali $\left(21^{\circ} 56^{\prime} 33^{\prime \prime} \mathrm{N}\right.$; $88^{\circ} 25^{\prime}$ 94" E): Around $3 \mathrm{~km}$ from Frasergunj, this is a sea side resort with long beach bordered by Casuarina trees and presently characterized by the formation of an enormous tidal flat. The area with many sanctuaries, fisheries and resorts is highly perturbed and its flora and fauna are under enormous stress of being constantly over-exploited, with very little measures taken by the concerned authorities. 
Frasergunj $\left(21^{\circ} 35^{\prime} 55.33^{\prime \prime} \mathrm{N}\right.$; $88^{\circ} 14^{\prime} 48.53^{\prime \prime}$ E): Originally known as Narayantala, Frasergunj is a relatively pristine white beach (greatly disturbed during Hilsa and Winter Migratory fisheries), stretching $7 \mathrm{~km}$ across with high marine influence.

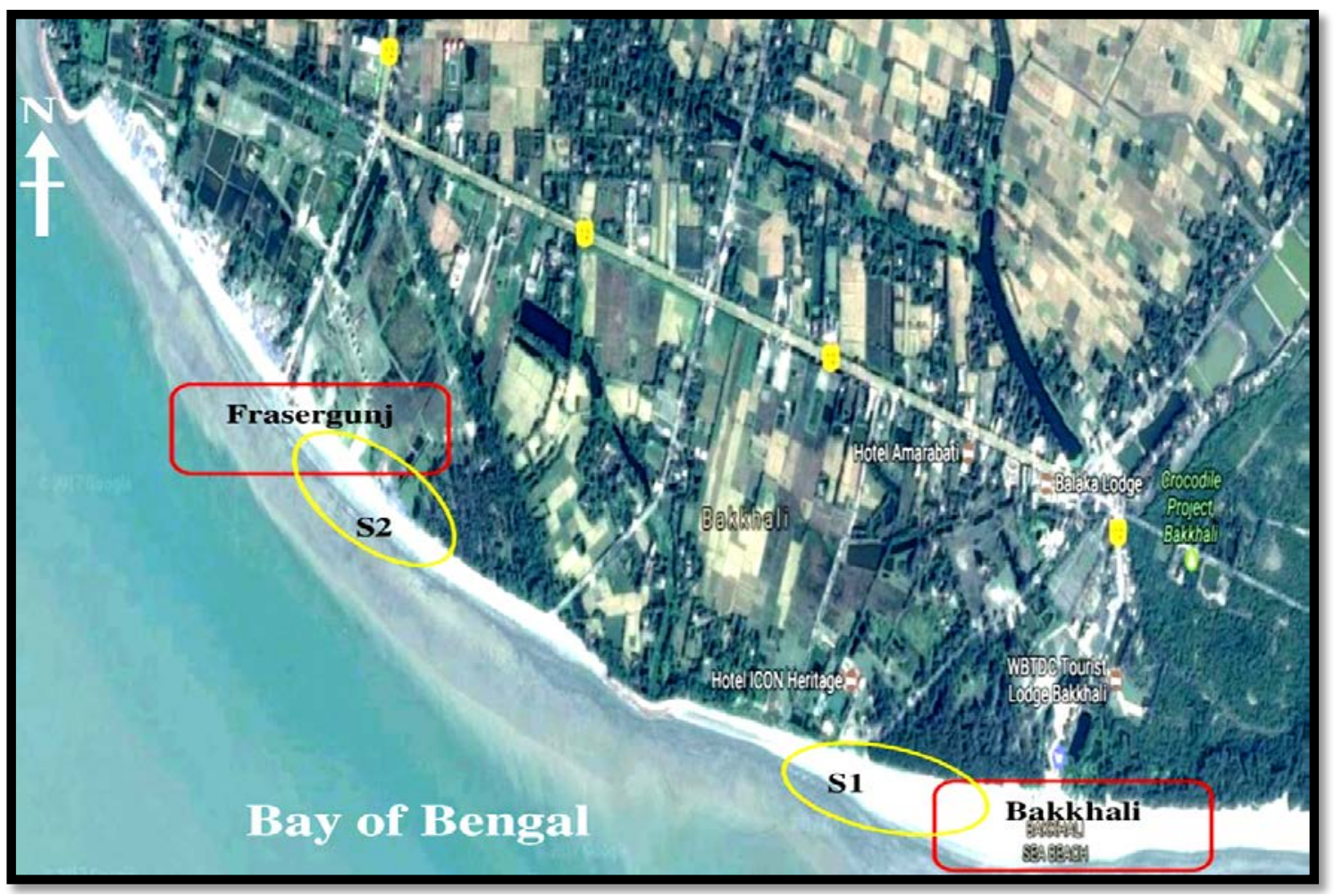

Figure 1. The map of study area pointing out the Bakkhali [S1] and Frasergunj [S2] Beach.

The intertidal beach of both Bakkhali and Fraserganj is thickly populated with red ghost and sand bubbler crabs. These species are important agents of bioturbation and cause on the horizontal and vertical stratification of the beach sediments. The edaphic nature of Fraserganj Beach is muddy (more than Bakkhali) and silt with prominent (rhomboidal, lenticular, conchoidal) beach features. On the other hand, absence of mangrove vegetation and the coastal processes along with the anthropogenic stress have rendered the Bakkhali Beach to accumulate more sand than silt and mud. Compared to Fraserganj, Bakkhali Beach is more bioturbated. The salient feature of the continuous beach of Fraserganj and Bakkhali is the presence of Casuarina trees and characteristic sand dunes.

\section{Collection of samples}

The study was performed in the premonsoon period [March to June] of the year 2017 and beach sediments and water samples were collected from Bakkhali and Frasergunj. Littoral areas at Bakkhali and Frasergunj of 1,000 and $800 \mathrm{sq} \mathrm{ft}$, respectively, were delineated for collecting samples at an interval of every $10 \mathrm{ft}$ while segmenting the traversed beach area into 11 and 9 zones, respectively, encompassing the supralittoral, littoral and sublittoral zones [Bakkhali: Supralittoral Zone (SPZ 
1), SPZ 2, Upper Littoral Zone (L1-L3), Middle Littoral Zone (L4-L5), Lower Littoral Zone (L6-L9) and Sublittoral Zone (L10); Frasergunj: Supralittoral Zone (SPZ ), Upper Littoral Zone (L1-L2), Middle Littoral Zone (L4-L6), Lower Littoral Zone (L7-L8) and Sublittoral Zone (L8), respectively].

The sediments were collected ascetically using sterilized spatula from the upper $2.5 \mathrm{~cm}$ of the surface of the beach before the onset of the high tide when there was less turbulence and churning. From each hypothesized zone, samples were collected in triplicates.

The sediment samples were kept in sterilized containers under refrigerated conditions and upon returning to the laboratory $5 \mathrm{~g}$ of the wet sediment sample from each of the collected sample stock were placed in polythene beakers and $50 \mathrm{~mL}$ of $2 \mathrm{M} \mathrm{KCl}$ was added to each for extraction of inorganic compounds such as dissolved nitrogen salts. The beakers were kept undisturbed for a period of one week in room temperature.

\section{Analysis and estimation}

This section is subdivided under two distinct headings dealing with analytical estimations and statistical analyses as follows:

Estimative analyses. The sediment sample and water samples collected during the study period were subjected to analytical studies of dissolved inorganic nitrogen species viz. ammonia nitrogen, nitrite-nitrogen, nitrate-nitrogen and Total dissolved Nitrates by following Grasshoff et al. (1983) and APHA (1998) and their respective concentrations were represented as $\mu \mathrm{mol} . \mathrm{L}^{-1}$ or $\mu \mathrm{M}$.

Statistical analyses. The data obtained and generated during the present study were interpreted with the help of regression, t-tests, ANOVA, f-tests, correlations and descriptive statistics etc. The statistical analyses for the study were performed with the help of Microsoft Excel 2007 software data analysis tool pack and XLSTAT 2015.1.

\section{Results and discussion}

The present study was performed with the objective of studying the littoral compartments of the Bakkhali and Frasergunj Beach located at the north western coast of Bay of Bengal at the southernmost tip of the Indian state of West Bengal. The data generated through observation, collection and estimation of the variables considered for the study i.e. the dissolved inorganic nitrogen species, viz. Nitrite-nitrogen, nitrate-nitrogen, ammonia-nitrogen, total dissolved nitrogen and cumulative concentration of nitrite-nitrogen, nitrate-nitrogen and ammonia-nitrogen are represented as follows.

The post high tide (spring) beach was selected at both the locations as they lie on the same shoreline. Depending on the number of large burrows (1- > 2" of inner diameter at the entrance) the zones were designated as NBT or no bioturbation, BT or bioturbated (no. of burrows per sqft 1-2), HBT or Heavily bioturbated (no. of burrows per sqft $>5$ ) and LBT or lower than heavily bioturbated (no. of burrows per sqft $>2<5$ ). The burrows were mostly excavated by ghost crab species (Ocypode brevicornis H. Milne-Edwards, 1837; Ocypode macrocera H. Milne-Edwards, 1852 and Ocypode ceratophthalma Pallas, 1772) sand bubbler crabs (Dotilla myctiroides H. Milne-Edwards, 1852) or Blue Soldier crabs (Myctris longicarpus Latreille, 1806). 

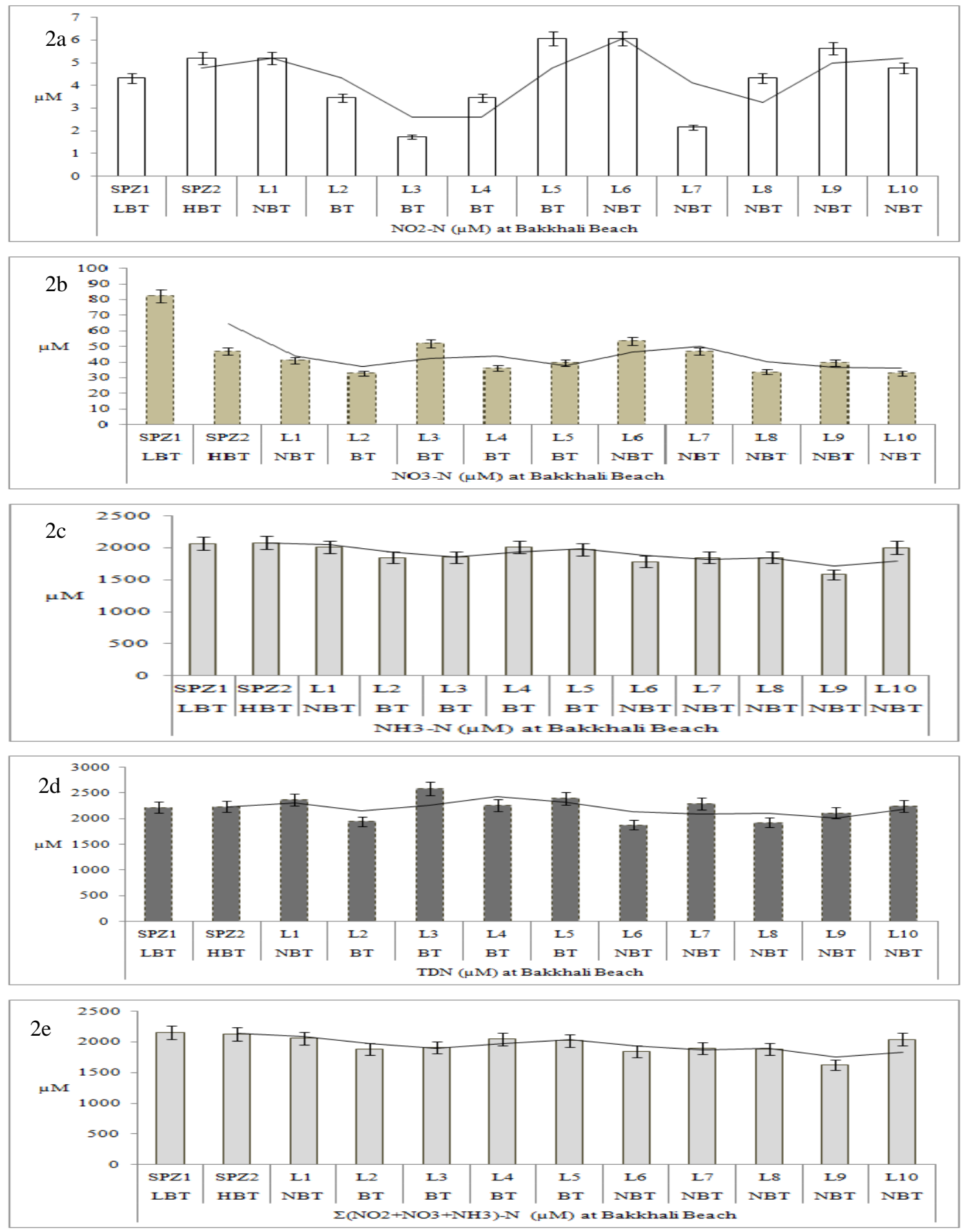

Figure 2. Variations in the mean concentrations $(\mu \mathrm{M})$ of dissolved inorganic nitrogen species in surface sediments of different beach zones at Bakkhali; $\mathbf{a}-\mathrm{NO}_{2}-\mathrm{N}, \mathbf{b}-\mathrm{NO}_{3}-\mathrm{N}, \mathbf{c}-\mathrm{NH}_{3}-\mathrm{N}, \mathbf{d}-\mathrm{TDN}$ and e - $\Sigma\left(\mathrm{NO}_{2}, \mathrm{NO}_{3}, \mathrm{NH}_{3}\right)-\mathrm{N}$. 
In case of Bakkhali (Figure 2a-e), the SPZ1 and SPZ2 were designated LBT and HBT; L1, L2 and L3 were NBT, BT and BT; L4, L5 and L6 were BT, BT and NBT; L7 downward up to L10 registered no bioturbations, respectively. At the
Frasergunj Beach (Figure 3a-e), SPZ was designated as HBT; L1-L2 were HBT and BT; L3-L5 were NBT; L6-L7 were bioturbated with L8 having no bioturbatory features, respectively.
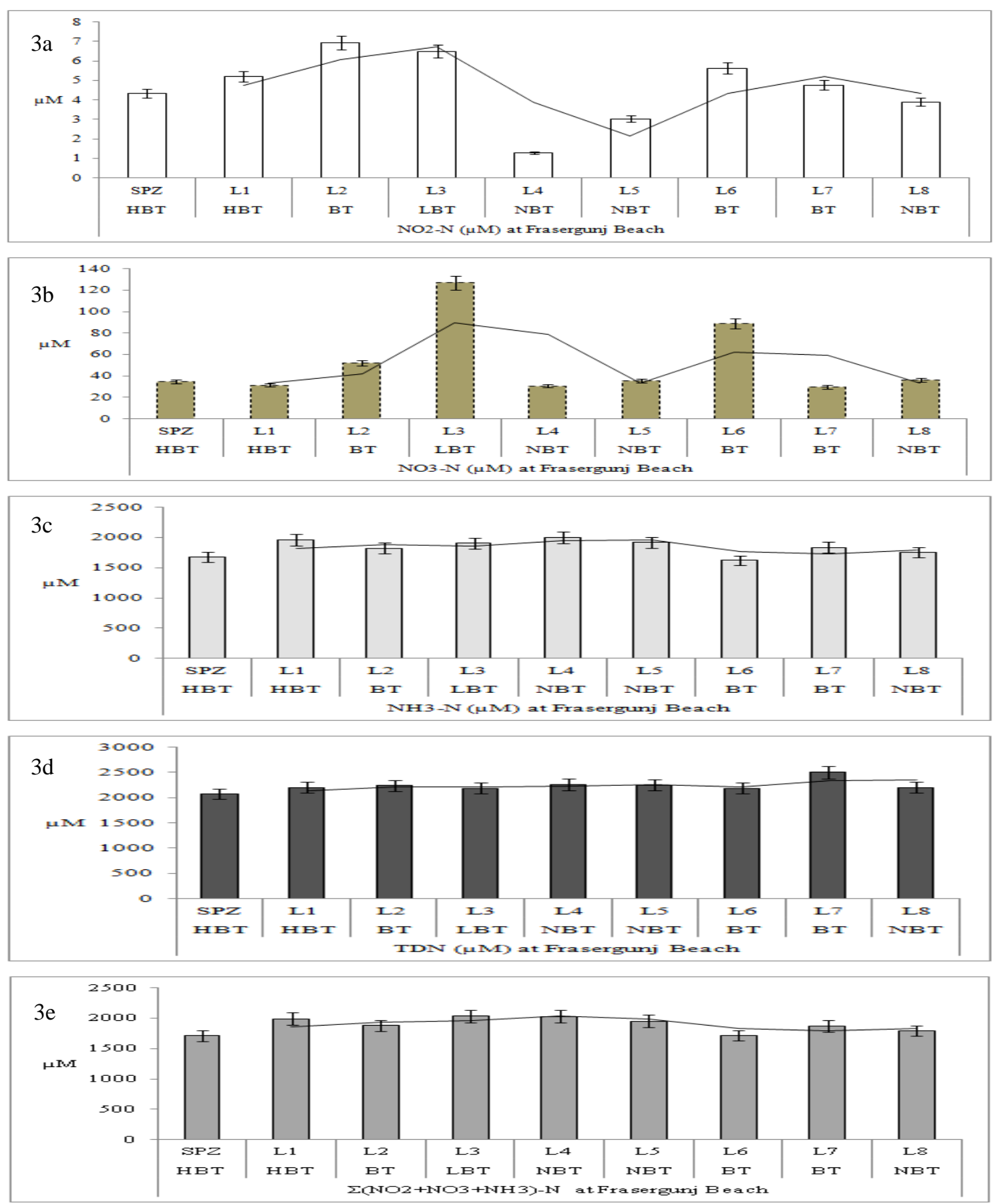

Figure 3. Changes in the mean concentrations $(\mu \mathrm{M})$ of dissolved inorganic nitrogen species in surface sediments of various beach zones at Frasergunj; $\mathbf{a}-\mathrm{NO}_{2}-\mathrm{N}, \mathbf{b}-\mathrm{NO}_{3}-\mathrm{N}, \mathbf{c}-\mathrm{NH}_{3}-\mathrm{N}, \mathbf{d}-\mathrm{TDN}$ and e - $\Sigma\left(\mathrm{NO}_{2}, \mathrm{NO}_{3}, \mathrm{NH}_{3}\right)-\mathrm{N}$. 
At Bakkhali (Figure 2a), nitritenitrogen was found to appear in fluctuating patterns throughout the beach zonations with gradual lowering and peaking within each zone with the highest and lowest mean values recorded in the sediments of the middle littoral and upper littoral zone at $5.19 \pm 0.14 \mu \mathrm{M}$ and $3.46 \pm 0.07 \mu \mathrm{M}$, respectively. At Frasergunj Beach the highest and lowest nitrite-nitrogen (Figure 3a) values recorded were $6.06 \pm 1.03 \mu \mathrm{M}$ and $3.89 \pm 0.61 \mu \mathrm{M}$ in the upper and middle littoral zones, respectively.

Dissolved nitrate-nitrogen (Figure 2b) at Bakkhali followed a gradually decreasing trend in general with the highest values within the supralittoral zone at $64.65 \pm 5.99 \mu \mathrm{M}$. With values such as $78.66 \pm 3.32 \mu \mathrm{M}$ and $34.59 \pm 1.70 \mu \mathrm{M}$, the middle littoral and supralittoral zones at Frasergunj docketed the comparatively higher and lower values of nitrite-nitrogen (Figure $3 b)$. From Figure 2c it is discernible that highest and lowest dissolved ammonia values were obtained from supralittoral and lower littoral zone sediments at $2073.56 \pm 89.03 \mu \mathrm{M}$ and $1761.23 \pm 45.83$ $\mu \mathrm{M}$, respectively. Frasergunj once again yielded highest $(1950.36 \pm 101.53 \mu \mathrm{M})$ and lowest $(1671.48 \pm 88.12 \mu \mathrm{M})$ values in case of ammonia-nitrogen at the middle and supralittoral zone (Figure 3c).

Upon analyzing the total dissolved nitrogen (Figure 2d) contents of the Bakkhali Beach sediments it was found that upper littoral zone and lower littoral zone exhibited the relatively higher and lower values at $2298.66 \pm 90.10 \mu \mathrm{M}$ and $2107.25 \pm 30.38$ $\mu \mathrm{M}$, respectively. Looking at Figure $3 \mathrm{~d}$ one can observe that the relative low TDN value has been generated from sediments of the supralittoral zone $(2078.33 \pm 60.15 \mu \mathrm{M})$ but the highest was recorded from sediments of the lower littoral zone $(2343.57 \pm 91.33 \mu \mathrm{M})$ at Frasergunj.

The Figure 2e represents cumulative concentration of the nitrite, nitrate and ammonia-nitrogen and the highest and lowest values were observed in the supralittoral and lower littoral zone at $2142.97 \pm 57.30 \mu \mathrm{M}$ and $1805.35 \pm 41.22 \mu \mathrm{M}$, respectively. Middle littoral and supralittoral zones at Frasergunj revealed the highest and lowest values of $2032.91 \pm 110.93 \mu \mathrm{M}$ and $1710.40 \pm 56.63 \mu \mathrm{M}$, respectively (Figure $3 e$ ). The subtraction of the TDN data by the cumulative concentration of the nitrogen species should yield the tentative concentrations of nitrogen species which are non-reactive or are in colloid phase that cannot be analyzed and estimated through the use of estimative processes applied successfully for the others.

A degree of independence was noted in the dissolved inorganic nitrogen species in the sediments of the bioturbated regions through the perturbances of bioturbators, at least in the surface sediments of wave exposed littoral sections of the sampling sites. This might have become significant in a vertical profile but from the data procured it can be stated that inorganic nitrogen species concentrations in surface beach sediments are not significantly perturbed by presence of bioturbatory features such as burrows of decapods species but as the same decapods species sieve the surface sediment during low tide, their role in the eventual stoichiometry of the dissolved nitrogen species may not be neglected.

The Figure 4 represents a comparative account of the inorganic dissolved nitrogen species present in the ambient waters around Bakkhali and Frasergunj Beach. As it is evident from the two charts the total dissolved nitrogen concentration was far greater than the cumulative concentrations of the nitrite-, nitrate- and ammonianitrogen. The deficit might be explained by the presence of colloidal nitrogenous compounds which could not be dealt with in the absence of proper amenities. Dissolved ammonia concentrations in the 
waters associated with both the stations were far less compared to the sediments as was nitrite-nitrogen because sediments harbour more organisms than do water and larger number of organisms with greater quantity of faecal matter and increased action of decomposers help release much more ammonia and in aerobic conditions that gets converted to nitrites by denitrifiers and ultimately to more stable nitrates. That is the reason sediment free water has more nitrates compared to either nitrites or ammonia.

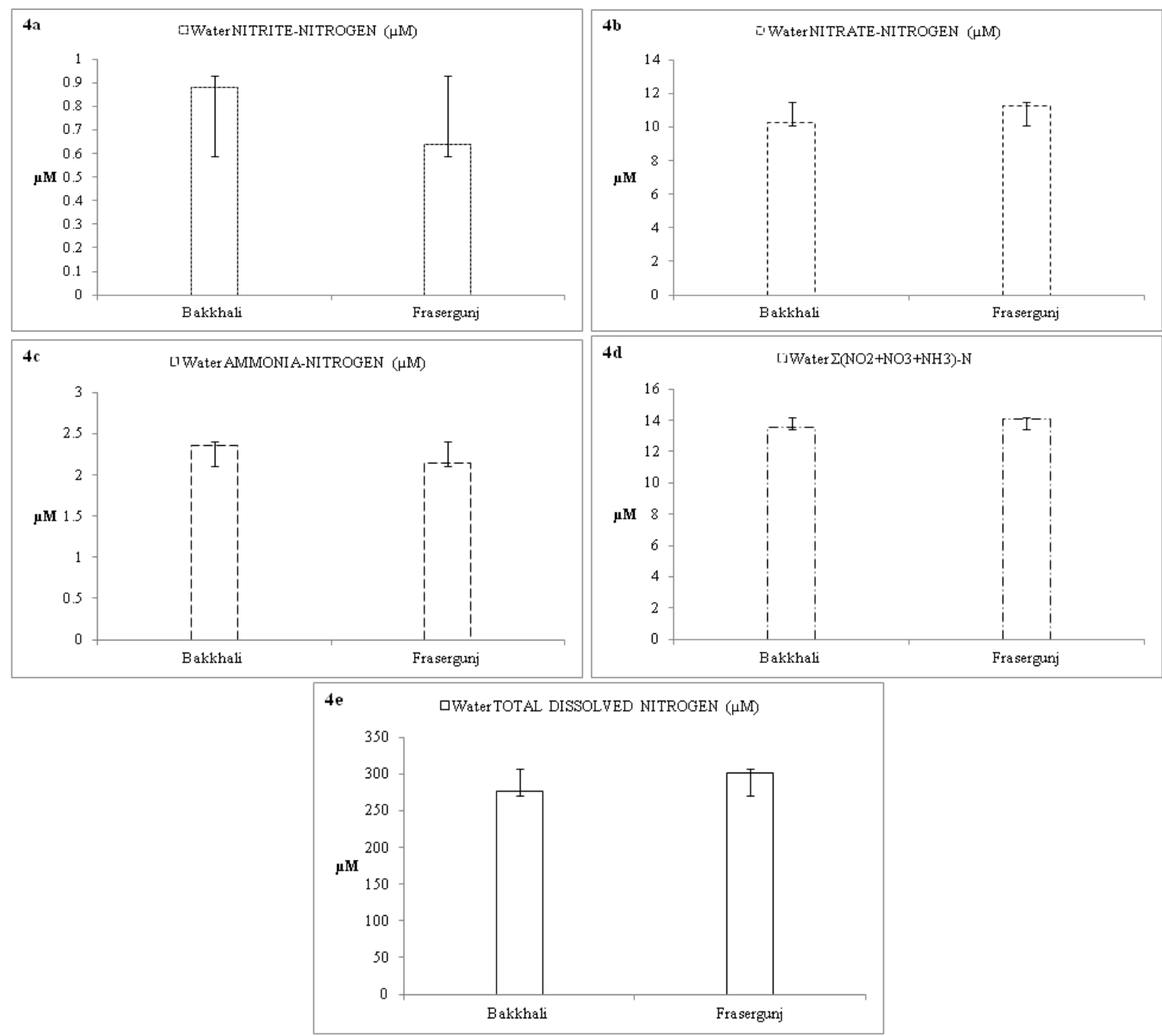

Figure 4. Comparative account of the mean concentrations (with std. deviations) of dissolved inorganic nitrogen $(\mu \mathrm{M})$ species in coastal waters immediately in the vicinity of the littoral section at Bakkhali and Frasergunj; 4a-dissolved nitrite-nitrogen, 4b - Nitrate-nitrogen, 4c - Ammonianitrogen, $4 \mathrm{~d}-\Sigma\left(\mathrm{NO}_{2}-\mathrm{N}, \mathrm{NO}_{3}-\mathrm{N}, \mathrm{NH}_{3}-\mathrm{N}\right)$, and $4 \mathrm{e}-$ Total dissolved nitrogen.

A zone wise comparison (Figure 5) was performed taking the mean values of the selected study variables based on data procured from sediments samples of Bakkhali and Frasergunj and although apparently the charts appear random but there seem to exist reservations among the high and low extremes among the variables. $\mathrm{NO}_{2}-\mathrm{N}$ and $\mathrm{NO}_{3}-\mathrm{N}$ appear to range in between $3.46 \pm 0.07 \mu \mathrm{M}$ to $6.06 \pm 1.03 \mu \mathrm{M}$ and $32.94 \pm 2.17 \mu \mathrm{M}$ to $78.66 \pm 3.32 \mu \mathrm{M}$ in all the investigated 
littoral zone surface sediments of Bakkhali and Frasergunj. Dissolved inorganic ammonia-nitrogen, total dissolved nitrogen or the cumulative concentration of the $\mathrm{NO}_{2}-\mathrm{N}, \mathrm{NO}_{3}-\mathrm{N}$ and $\mathrm{NH}_{3}-\mathrm{N}$ appear to be reserved also considering every littoral zone sampled
$\left[\mathrm{NH}_{3}-\mathrm{N}: \quad 1671.48 \pm 88.12 \mu \mathrm{M} \quad\right.$ to $2073.56 \pm 89.03 \mu \mathrm{M}$; TDN: $2078.33 \pm 60.15$ $\mu \mathrm{M}$ to $2343.57 \pm 91.33 \mu \mathrm{M}$; and $\Sigma\left(\mathrm{NO}_{2}-\mathrm{N}\right.$, $\mathrm{NO}_{3}-\mathrm{N}, \mathrm{NH}_{3}-\mathrm{N}$ ): $1710.40 \pm 56.63 \mu \mathrm{M}$ to $2142.97 \pm 57.30 \mu \mathrm{M}]$ and not any one littoral zone appeared to dominate over the other.
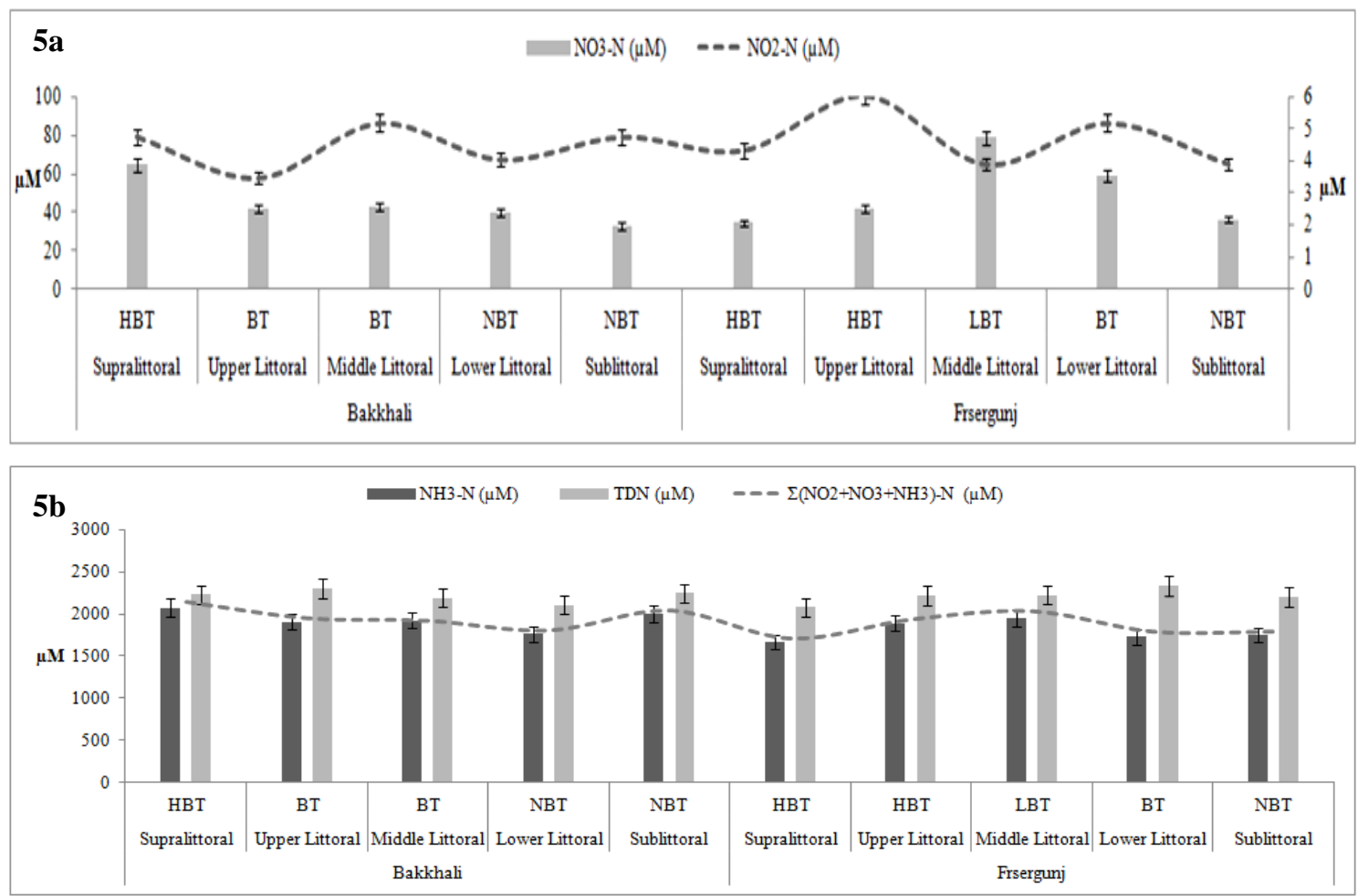

Figure 5. Comparative variations in the mean concentrations of dissolved inorganic nitrogen $(\mu \mathrm{M})$ species in various beach zone (supralittoral, upper-, mid-, lower littoral and subtidal) sediments of Bakkhali and Frasergunj; a - Nitrite-nitrogen and nitrate-nitrogen, b - Ammonianitrogen, total dissolved nitrogen and cumulative concentration of the estimated nitrite-, nitrateand ammonia-nitrogen.

The apparent homogeneity in the distribution of the dissolved nitrogen species throughout the study sites is because the sediments exposed to air and diurnal tidal influences are more or less shuffled and only depending upon the accumulation of organic matters in beach sediment ripple troughs can certain sectors show greater concentration of one or more variables under observation but the mean values of nitrogen species at the surface of various littorla segments remain more or less similar.

Although the mean values differ in case of each of the variables and stations, on the whole (all the beach zonations combined) the values show uncanny similarity and thus underlines the homogeneity of the variables at the surface of the sediments irrespective of the presence or absence bioturbatory features [Bakkhali - $\mathrm{NO}_{2}-\mathrm{N}: 4.44 \pm 0.14$ 
$\mu \mathrm{M}, \quad \mathrm{NO}_{3}-\mathrm{N}: \quad 44.55 \pm 9.05 \quad \mu \mathrm{M}, \quad \mathrm{NH}_{3}-\mathrm{N}:$ $1933.40 \pm 80.38 \quad \mu \mathrm{M}, \quad \mathrm{TDN}$ : $2212.86 \pm 106.75 \mu \mathrm{M}$ and $\Sigma\left(\mathrm{NO}_{2}-\mathrm{N}_{1} \mathrm{NO}_{3}\right.$ $\mathrm{N}, \mathrm{NH}_{3}-\mathrm{N}$ ): $1972.38 \pm 67.75 \mu \mathrm{M}$; Frasergunj - $\quad \mathrm{NO}_{2}-\mathrm{N}: \quad 4.67 \pm 0.23 \mu \mathrm{M}, \quad \mathrm{NO}_{3}-\mathrm{N}$ :
$50.12 \pm 13.62 \mu \mathrm{M}, \mathrm{NH}_{3}-\mathrm{N}: 1797.85 \pm 112.05$ $\mu \mathrm{M}, \quad \mathrm{TDN}: 2213.00 \pm 137.33 \mu \mathrm{M}$ and $\Sigma\left(\mathrm{NO}_{2}-\mathrm{N}, \mathrm{NO}_{3}-\mathrm{N}, \mathrm{NH}_{3}-\mathrm{N}\right): 1852.60 \pm 88.26$ $\mu \mathrm{M}]$.

Table 1. Stoichiometric ratio between the inorganic dissolved nitrogen, phosphorus species and silicate concentrations yielded after analytical estimations on sediment and water samples collected at Bakkhali Beach.

\begin{tabular}{|c|c|c|c|c|c|c|c|c|}
\hline & Ratio $\rightarrow$ & $\begin{array}{l}\mathrm{NO}_{2}-\mathrm{N}: \\
\mathrm{NO}_{3}-\mathrm{N}\end{array}$ & $\begin{array}{l}\mathrm{NO}_{2}-\mathrm{N}: \\
\mathrm{NH}_{3}-\mathrm{N}\end{array}$ & $\begin{array}{c}\mathrm{NO}_{2}-\mathrm{N}: \\
\text { TDN }\end{array}$ & $\begin{array}{l}\mathrm{NO}_{3}-\mathrm{N}: \\
\mathrm{NH}_{3}-\mathrm{N}\end{array}$ & $\begin{array}{c}\mathrm{NO}_{3}-\mathrm{N}: \\
\text { TDN }\end{array}$ & $\begin{array}{c}\mathrm{NH}_{3}-\mathrm{N}: \\
\text { TDN }\end{array}$ & $\begin{array}{c}\mathrm{TDN}: \Sigma\left(\mathrm{NO}_{2}\right. \\
\left.+\mathrm{NO}_{3}+\mathrm{NH}_{3}\right) \\
-\mathrm{N} \\
\end{array}$ \\
\hline \multirow{13}{*}{ Zone } & SPZ1 $^{*}$ & 0.0526 & 0.0021 & 0.0020 & 0.0398 & 0.0371 & 0.9322 & 1.0296 \\
\hline & SPZ2 & 0.1108 & 0.0025 & 0.0023 & 0.0226 & 0.0210 & 0.9296 & 1.0494 \\
\hline & L1 & 0.1263 & 0.0026 & 0.0022 & 0.0205 & 0.0174 & 0.8511 & 1.1484 \\
\hline & L2 & 0.1050 & 0.0019 & 0.0018 & 0.0178 & 0.0169 & 0.9510 & 1.0313 \\
\hline & L3 & 0.0333 & 0.0009 & 0.0007 & 0.0280 & 0.0201 & 0.7168 & 1.3559 \\
\hline & L4 & 0.0955 & 0.0017 & 0.0015 & 0.0180 & 0.0160 & 0.8899 & 1.1020 \\
\hline & L5 & 0.1533 & 0.0031 & 0.0025 & 0.0200 & 0.0165 & 0.8242 & 1.1859 \\
\hline & L6 & 0.1132 & 0.0034 & 0.0032 & 0.0300 & 0.0285 & 0.9491 & 1.0196 \\
\hline & L7 & 0.0460 & 0.0012 & 0.0009 & 0.0254 & 0.0205 & 0.8090 & 1.2042 \\
\hline & L8 & 0.1283 & 0.0023 & 0.0022 & 0.0183 & 0.0175 & 0.9600 & 1.0206 \\
\hline & L9 & 0.1424 & 0.0036 & 0.0027 & 0.0250 & 0.0188 & 0.7514 & 1.2939 \\
\hline & L10 & 0.1445 & 0.0024 & 0.0021 & 0.0164 & 0.0147 & 0.8933 & 1.0987 \\
\hline & Water & 0.0855 & 0.3729 & 0.0032 & 4.3602 & 0.0372 & 0.0085 & 20.4627 \\
\hline
\end{tabular}

*SPZ1 = Upper Supralittoral Zone, SPZ2 = Lower Littoral Zone, L1-L3 = Upper Littoral Zone, L4-L6 = Mid Littoral Zone, L7-L9 = Lower Littoral Zone, L10 = Sublittoral Zone; Area of each unit is 10 sqft.

Table 2. Stoichiometric ratio between the inorganic dissolved nitrogen, phosphorus species and silicate concentrations yielded after analytical estimations on sediment and water samples collected at Frasergunj Beach.

\begin{tabular}{|c|c|c|c|c|c|c|c|c|}
\hline & Ratio $\rightarrow$ & $\begin{array}{r}\mathrm{NO}_{2}-\mathrm{N}: \\
\mathrm{NO}_{3}-\mathrm{N}\end{array}$ & $\begin{array}{r}\mathrm{NO}_{2}-\mathrm{N}: \\
\mathrm{NH}_{3}-\mathrm{N}\end{array}$ & $\begin{array}{r}\mathrm{NO}_{2}-\mathrm{N}: \\
\text { TDN }\end{array}$ & $\begin{array}{c}\mathrm{NO}_{3}-\mathrm{N}: \\
\mathrm{NH}_{3}-\mathrm{N}\end{array}$ & $\begin{array}{r}\mathrm{NO}_{3}-\mathrm{N}: \\
\text { TDN }\end{array}$ & $\begin{array}{r}\mathrm{NH}_{3}-\mathrm{N}: \\
\text { TDN }\end{array}$ & $\begin{array}{c}\mathrm{TDN}: \Sigma\left(\mathrm{NO}_{2}\right. \\
\left.+\mathrm{NO}_{3}+\mathrm{NH}_{3}\right) \\
-\mathrm{N}\end{array}$ \\
\hline \multirow{10}{*}{ Zone } & SPZ & 0.1252 & 0.0026 & 0.0021 & 0.0207 & 0.0166 & 0.8042 & 1.2151 \\
\hline & L1 & 0.1662 & 0.0027 & 0.0024 & 0.0160 & 0.0142 & 0.8884 & 1.1050 \\
\hline & L2 & 0.1336 & 0.0038 & 0.0031 & 0.0285 & 0.0232 & 0.8135 & 1.1907 \\
\hline & L3 & 0.0512 & 0.0034 & 0.0030 & 0.0666 & 0.0580 & 0.8699 & 1.0743 \\
\hline & L4 & 0.0423 & 0.0006 & 0.0006 & 0.0153 & 0.0135 & 0.8850 & 1.1122 \\
\hline & L5 & 0.0856 & 0.0016 & 0.0013 & 0.0185 & 0.0157 & 0.8506 & 1.1525 \\
\hline & L6 & 0.0633 & 0.0035 & 0.0026 & 0.0549 & 0.0407 & 0.7418 & 1.2737 \\
\hline & L7 & 0.1606 & 0.0026 & 0.0019 & 0.0162 & 0.0118 & 0.7327 & 1.3398 \\
\hline & L8 & 0.1076 & 0.0022 & 0.0018 & 0.0207 & 0.0165 & 0.7961 & 1.2279 \\
\hline & Water & 0.0567 & 0.2977 & 0.0021 & 5.2465 & 0.0373 & 0.0071 & 21.4826 \\
\hline
\end{tabular}

*SPZ = Supralittoral Zone, L1-L3 = Upper Littoral Zone, L4 = Mid Littoral Zone, L5-L7 = Lower Littoral Zone, L8 = Sublittoral Zone; Area of each unit is 10 sqft. 
In comparison Frasergunj had registered higher mean values in most of the cases but ammonia. The reason behind Bakkhali having higher ammonia in the surface sediments lies in its tourism trade and large anthropogenic stresses in the form of litter, sewage, raw excrements etc almost always leads to the rise in ammonia. Frasergunj on the other hand is more silty and muddy in nature, thus retain greater organic load and hence the increase in variables like nitrite and nitrates. But the notion of the homogeneity comes from the observation on the values yielded from TDN or $\Sigma\left(\mathrm{NO}_{2}-\mathrm{N}, \mathrm{NO}_{3}-\mathrm{N}, \mathrm{NH}_{3}-\mathrm{N}\right)$ which are almost similar in the two different beach sediment. Bakkhali and Frasergunj seat on a single stretch that runs for almost 7 miles. In spite of the localized differences in the physico-chemical characteristics, the surface beach sediment stoichiometry as far as the dissolved nitrogen species are concerned, on a magnified scale, level out.

The Tables 1 and 2 dealing with the stoichiometric ratio of the selected variables along the various sampling zones within the littoral compartments highlight the issue discussed in the earlier section succinctly. Nitritenitrogen concentrations had bearing upon the concentrations of nitratenitrogen and ammonia-nitrogen concentration governed the ratio between it and total dissolved nitrogen since in the benthic environment ammonia appeared to be the most abundant of inorganic nitrogen species and the $\Sigma\left(\mathrm{NO}_{2}-\mathrm{N}, \mathrm{NO}_{3}-\mathrm{N}, \mathrm{NH}_{3}-\mathrm{N}\right)$ was understandably found to have significant bearing over the TDN in both sediments and water samples. The $\mathrm{NO}_{2}-\mathrm{N}: \mathrm{NH}_{3}-\mathrm{N}$ and $\mathrm{NO}_{3}-\mathrm{N}: \mathrm{NH}_{3}-\mathrm{N}$ in the water had more significant values, implying the interdependence on the presence of one for the existence of the other. There is significance in the variances of means [p at 0.05 ] of the data sets obtained from the estimations of nitrogen species in beach sediment and water samples of Bakkhali and Frasergunj (Table 3 and 4, respectively) with $\mathrm{F}>>\mathrm{F}$ critical [ANOVA: Single factor] thereby implying the rejection of the Null hypothesis.

Table 3. ANOVA: Single factor performed on the set of data obtained from the estimations of nitrogen species in beach sediment and water at Bakkhali.

\begin{tabular}{|c|c|c|c|c|c|c|}
\hline Groups & Count & Sum & Average & Variance & & \\
\hline $\mathrm{NO}_{2}-\mathrm{N}(\mu \mathrm{M})$ & 10 & 41.99 & 4.199 & 2.256743 & & \\
\hline $\mathrm{NO}_{3}-\mathrm{N}(\mu \mathrm{M})$ & 10 & 465.29 & 46.529 & 210.3579 & & \\
\hline $\mathrm{NH}_{3}-\mathrm{N}(\mu \mathrm{M})$ & 10 & 19330.25 & 1933.025 & 11400.21 & & \\
\hline $\operatorname{TDN}(\mu \mathrm{M})^{*}$ & 10 & 22097.43 & 2209.743 & 52178.75 & & \\
\hline \multicolumn{7}{|l|}{ ANOVA } \\
\hline Source of Variation & SS & df & MS & $\mathrm{F}$ & P-value & F crit \\
\hline Between Groups & 42253802 & 3 & 14084601 & 883.1636 & $9.49 \mathrm{E}-34$ & 5.483059 \\
\hline Within Groups & 574124.2 & 36 & 15947.89 & & & \\
\hline Total & 42827926 & 39 & & & & \\
\hline
\end{tabular}


Table 4. ANOVA: Single factor performed on the set of data obtained from the estimations of nitrogen species in beach sediment and water at Frasergunj.

\begin{tabular}{|c|c|c|c|c|c|c|}
\hline Groups & Count & Sum & Average & Variance & & \\
\hline $\mathrm{NO}_{2}-\mathrm{N}(\mu \mathrm{M})$ & 10 & 42.2 & 4.22 & 4.296556 & & \\
\hline $\mathrm{NO}_{3}-\mathrm{N}(\mu \mathrm{M})$ & 10 & 476.58 & 47.658 & 1183.587 & & \\
\hline $\mathrm{NH}_{3}-\mathrm{N}(\mu \mathrm{M})$ & 10 & 16472.37 & 1647.237 & 348758.5 & & \\
\hline $\operatorname{TDN}(\mu \mathrm{M})^{*}$ & 10 & 20404.73 & 2040.473 & 384570.2 & & \\
\hline \multicolumn{7}{|l|}{ ANOVA } \\
\hline Source of Variation & SS & $\mathrm{df}$ & MS & $\mathrm{F}$ & P-value & F crit \\
\hline Between Groups & 33830793 & 3 & 11276931 & 61.41144 & $3.12 \mathrm{E}-14$ & 5.483059 \\
\hline Within Groups & 6610649 & 36 & 183629.10 & & & \\
\hline Total & 40441442 & 39 & & & & \\
\hline
\end{tabular}

Table 5. Pearson correlation matrix on the homogenized data on the nitrogen species in different beach compartment sediments collected from Bakkhali and Frasergunj.

\begin{tabular}{|c|c|c|c|c|c|c|c|c|c|c|}
\hline Species $\downarrow \rightarrow$ & $\begin{array}{l}\mathrm{B} \\
\mathrm{NO}_{2-} \\
\mathrm{N}\end{array}$ & $\begin{array}{l}\mathrm{F} \\
\mathrm{NO}_{2-} \\
\mathrm{N}\end{array}$ & $\begin{array}{l}\mathrm{B} \\
\mathrm{NO}_{3-} \\
\mathrm{N}\end{array}$ & $\begin{array}{l}\mathrm{F} \\
\mathrm{NO}_{3-} \\
\mathrm{N}\end{array}$ & $\begin{array}{l}\mathrm{B} \\
\mathrm{NH}_{3-} \\
\mathrm{N}\end{array}$ & $\begin{array}{l}\mathrm{F} \\
\mathrm{NH}_{3}- \\
\mathrm{N}\end{array}$ & $\begin{array}{l}\text { B } \\
\text { TDN }\end{array}$ & $\begin{array}{l}\text { F } \\
\text { TDN }\end{array}$ & $\begin{array}{l}\mathrm{B} \\
\Sigma\left(\mathrm{NO}_{2}+\mathrm{N}\right. \\
\left.\mathrm{O}_{3}+\mathrm{NH}_{3}\right)- \\
\mathrm{N}\end{array}$ & $\begin{array}{l}\mathrm{F} \\
\Sigma\left(\mathrm{NO}_{2}+\mathrm{NO}_{3}+\right. \\
\left.\mathrm{NH}_{3}\right)-\mathrm{N}\end{array}$ \\
\hline $\mathrm{B}^{*} \mathrm{NO}_{2}-\mathrm{N}$ & 1.00 & & & & & & & & & \\
\hline $\mathrm{F} \mathrm{NO}_{2}-\mathrm{N}$ & -0.97 & 1.00 & & & & & & & & \\
\hline $\mathrm{B} \mathrm{NO}_{3}-\mathrm{N}$ & 0.18 & -0.06 & 1.00 & & & & & & & \\
\hline $\mathrm{F} \mathrm{NO}_{3}-\mathrm{N}$ & 0.32 & -0.19 & -0.24 & 1.00 & & & & & & \\
\hline $\mathrm{B} \mathrm{NH}_{3}-\mathrm{N}$ & 0.48 & -0.50 & 0.51 & -0.55 & 1.00 & & & & & \\
\hline $\mathrm{F} \mathrm{NH}_{3}-\mathrm{N}$ & 0.00 & 0.11 & -0.39 & 0.64 & -0.24 & 1.00 & & & & \\
\hline B TDN & -0.24 & 0.21 & 0.07 & -0.57 & 0.61 & 0.24 & 1.00 & & & \\
\hline F TDN & -0.38 & 0.35 & -0.71 & 0.52 & -0.96 & 0.23 & -0.59 & 1.00 & & \\
\hline $\begin{array}{l}\mathrm{B} \\
\Sigma\left(\mathrm{NO}_{2}+\mathrm{NO}_{3}+\right. \\
\left.\mathrm{NH}_{3}\right)-\mathrm{N}\end{array}$ & 0.36 & -0.39 & 0.58 & -0.68 & 0.98 & -0.38 & 0.60 & -0.96 & 1.00 & \\
\hline $\begin{array}{l}\mathrm{F} \\
\Sigma\left(\mathrm{NO}_{2}+\mathrm{NO}_{3}+\right. \\
\left.\mathrm{NH}_{3}\right)-\mathrm{N}\end{array}$ & 0.04 & 0.08 & -0.38 & 0.72 & -0.30 & 0.99 & 0.14 & 0.29 & -0.44 & 1.00 \\
\hline
\end{tabular}

${ }^{*} \mathrm{~B}=$ Bakkhali, $\mathrm{F}=$ Frasergunj.

Table 6. ANOVA: Single factor performed on the set of data obtained from the estimations of nitrogen species in beach sediment and water at Bakkhali and Frasergunj. The ANOVA was performed on data obtained from individual zonations in a comparative manner.

\begin{tabular}{|c|c|c|c|c|c|c|}
\hline Groups & Count & Sum & Average & Variance & & \\
\hline Bakkhali N02-N $(\mu \mathrm{M})$ & 5 & 22.215 & 4.443 & 0.47272 & & \\
\hline Frasergunj NO2-N $(\mu \mathrm{M})$ & 5 & 23.37 & 4.674 & 0.87983 & & \\
\hline Bakkhali NO3-N $(\mu \mathrm{M})$ & 5 & 222.75 & 44.55 & 141.8767 & & \\
\hline Frasergunj NO3-N $(\mu \mathrm{M})$ & 5 & 250.62 & 50.124 & 350.2816 & & \\
\hline Bakkhali NH3-N $(\mu \mathrm{M})$ & 5 & 9666.99 & 1933.398 & 13806.8 & & \\
\hline Frasergunj NH3-N $(\mu \mathrm{M})$ & 5 & 8989.3 & 1797.86 & 13599.06 & & \\
\hline Bakkhali TDN $(\mu \mathrm{M})$ & 5 & 11064.3 & 2212.86 & 5083.946 & & \\
\hline Frasergunj TDN $(\mu \mathrm{M})$ & 5 & 11065 & 2213 & 8862.555 & & \\
\hline Bakkhali $\Sigma(\mathrm{NO} 2+\mathrm{NO} 3+\mathrm{NH} 3)-\mathrm{N}$ & 5 & 9861.945 & 1972.389 & 16246.22 & & \\
\hline Frasergunj $\Sigma(\mathrm{NO} 2+\mathrm{NO} 3+\mathrm{NH} 3)-\mathrm{N}$ & 5 & 9263.04 & 1852.608 & 16731.35 & & \\
\hline \multicolumn{7}{|l|}{ ANOVA } \\
\hline Source of Variation & SS & $\mathrm{df}$ & MS & $\mathrm{F}$ & $\mathrm{P}$-value & F crit \\
\hline Between Groups & 47422739 & 9 & 5269193 & 704.217 & $3.86 \mathrm{E}-41$ & 2.124029 \\
\hline Within Groups & 299293.7 & 40 & 7482.343 & & & \\
\hline Total & 47722033 & 49 & & & & \\
\hline$\alpha>>P$; F >>F crit; Null Hypothesis & cted & & & & & \\
\hline
\end{tabular}


A Pearson correlation matrix (Table 5) performed on the homogenized data set on the nitrogen species variation in beach sediments of Bakkhali and Frasergunj revealed there exists a fairly significant interrelation between the two beach sediments with r-values ranging from -0.97 to +0.99 among the five variables considered at $95 \%$ confidence level. The concentration of nitrogen species in the ambient water mass at the study sites exhibited significant variances (at 0.05 level of confidence) along with the data obtained from the various beach sections (Table 6).

\section{Conclusion}

The present work was performed to observe the variations in the dissolved inorganic nitrogen species in the beach surface sediments in the littoral compartments of Bakkhali and Frasergunj and also to study the impact of the presence or absence of bioturbations on the variability of the dissolved inorganic nitrogen species viz. dissolved nitrate-nitrogen, nitritenitrogen, ammonia-nitrogen, total dissolved nitrogen and the cumulative concentration of first three variables in the beach surface sediments.

At Bakkhali and Frasergunj, nitrite-nitrogen was found to appear in fluctuating patterns throughout the beach zonations with gradual lowering and peaking within each zone. The $\mathrm{NO}_{2}-\mathrm{N}$ and $\mathrm{NO}_{3}-\mathrm{N}$ appear to range in between $3.46 \pm 0.07 \mu \mathrm{M}$ to $6.06 \pm 1.03 \mu \mathrm{M}$ and $32.94 \pm 2.17 \mu \mathrm{M}$ to $78.66 \pm 3.32 \mu \mathrm{M}$ in all the investigated littoral zone surface sediments of Bakkhali and Frasergunj. Dissolved inorganic ammonia-nitrogen, total dissolved nitrogen or the cumulative concentration of the $\mathrm{NO}_{2}-\mathrm{N}$, $\mathrm{NO}_{3}-\mathrm{N}$ and $\mathrm{NH}_{3}-\mathrm{N}$ appear to be reserved also considering every littoral zone sampled and not any one littoral zone appeared to dominate over the other. A very interesting fact that was evidently prominent was the independence of dissolved inorganic nitrogen species from bioturbatory influences in the surface sediments of wave exposed littoral environments like the beaches at Bakkhali and Frasergunj. From the data procured it can be stated that inorganic nitrogen species concentrations in surface beach sediments are not entirely perturbed by bioturbations and are governed by many other environmental parameters.

A Pearson correlation performed on the homogenized data sets revealed there exists a fairly significant interrelation between the beach sediments of the two beaches, with $\mathrm{r}$ values ranging from -0.97 to +0.99 among the five variables considered at 95\% confidence level. ANOVA Single factor performed on the data sets generated during the present study probability and critical values expressing rejection of the Null hypothesis which means there was significance in the variance of means of the data sets.

The study revealed many fascinating insights on the changes in concentrations of the dissolved inorganic nitrogen species within the surface littoral sediments and more rigorous efforts should be put in future to find out more intriguing ecological phenomena of tropical beach environments.

\section{Acknowledgement}

This study was a self financed and for which I would like to extend my sincerest and humblest of gratitude to the Head of the Department of Marine Science, University of Calcutta for supporting the study through the provision of valuable insights and the completely furnished laboratory to perform the work in. There exists no conflict of interests among the authors.

\section{Conflict of interest}

Authors declare that they have no conflict of interests. 


\section{References}

Aller, R. C. Quantifying solute distributions in the bioturbated zone of marine sediments by defining an average microenvironment. Geochimica et Cosmochimica Acta, v 44, p. 1955-1965, 1980. https://doi.org/10.1016/ 0016-7037(80)90195-7

APHA - American Public Health Association. Standard methods for the examination of water and wastewater. 20. ed. Baltimore, Maryland: United Book Press, 1998.

Bebout, B. M.; Paerl, H.W.; Bauer, J. E.; Canfield, D. E.; Des Marais, D. J. Nitrogen cycling in microbial mat communities: The quantitative importance of $\mathrm{N}$-fixation and other sources of $\mathrm{N}$ for primary productivity. In: Stal, L. J.; Caumette, P. (Ed.). Microbial mats, structure, development and environmental significance. Berlin: Springer-Verlag, 1994. (NATO ASI Series). p. 267-271.

Blackburn, T. H.; Sørensen, J. Nitrogen cycling in coastal marine environments. New York: John Wiley and Sons, 1988.

Blackburn, T. H.; Henriksen, K. Nitrogen cycling in different types of sediment from Danish waters. Limnology and Oceanography, v. 28, p. 477-493, 1983. https://doi.org/10.4319/lo.1983.28.3.0477

Caffrey, J. M.; Sloth, N. P.; Kaspar, H. F.; Blackburn, T.H. Effect of organic loading on nitrification and denitrification in a marine sediment mesocosm. FEMS Microbiology Ecology, v. 12, p. 159-169, 1993. https://doi.org/10.1111/j.1574-6941.1993. tb00028.x

Carpenter, E. J.; Capone, D. G. Nitrogen in the marine environment. New York: Academic Press, 1983.

Dugdale, R. C.; Goering, J. J. Uptake of new and regenerated forms of nitrogen in primary productivity. Limnology and Oceanography, v. 12, p. 196-206, 1967. https://doi.org/10.4319/lo.1967.12.2.0196

Glibert, P. M. Primary productivity and pelagic nitrogen cycling. In: Blackburn, T. H.; Sørensen, J. (Ed.). Nitrogen cycling in coastal marine environments. New York: John Wiley and Sons, 1988. p. 3-31.

Goldhaber, M. B.; Aller, R. C.; Cochran, J. K.; Rosenfield, J. K.; Martens, C. S.; Berner, R. A. Sulfate reduction, diffusion and bioturbation in Long Island Sound sediments: Report of the FOAM Group. American Journal of Science, v. 277, p. 193-237, 1977. https://doi.org/10.2475/ajs.277.3.193

Grasshoff, K.; Ehrhardt, M.; Kremling, K. (Ed.). Methods of seawater analysis. 2. ed. Berlin: Verlag Chemie, 1983.

Hecky, R. E.; Kilham, P. Nutrient limitation of phytoplankton in freshwater and marine environments: A review of recent evidence on the effects of enrichment. Limnology and Oceanography, v. 33, p. 796-822, 1988. https://doi.org/10.4319/lo.1988.33.4part2.0 796

Herbert, R. A. Nitrogen cycling in coastal marine ecosystems. FEMS Microbiology Ecology, v. 23, p. 563-590, 1999. https://doi.org/10.1111/j.1574-6976.1999. tb00414.x

Herbert, R. A.; Nedwell, D. B. Role of environmental factors in regulating nitrate respiration in intertidal sediments. In: Revsbech, N. P.; Sørensen, J. (Ed.). Denitrification in soil and sediment. New York: Plenum Press, 1990. p. 77-90.

Hines, M. E.; Knollmeyer, S. I.; Tugel, J. B. Sulfate reduction and other sedimentary biogeochemistry in a Northern New England salt marsh. Limnology and Oceanography, v. 34 , p. 578-590, 1989 . https://doi.org/ 10.4319/lo.1989.34.3.0578

Howarth, R. W.; Marino, R.; Lane, J.; Cole, J. J. Nitrogen fixation in freshwater, estuarine and marine ecosystems. 1. Rates and importance. Limnology and Oceanography, v. 33, p.619-687, 1988. https://doi.org/ 10.4319/lo.1988.33.4part2.0669

Jensen, H. J.; Lomstein, E.; Sørensen, J. Benthic $\mathrm{NH}_{4}{ }^{+}$and $\mathrm{NO}_{3}{ }^{-}$flux following sedimentation of a spring phytoplankton bloom in Aarhus Bight, Denmark. Marine Ecology Progress Series, v. 61, p. 87-96, 1990.

Jørgensen, B. B.; Revsbech, N. P. Oxygen uptake, bacterial distribution and carbonnitrogen-sulfur cycling in sediments from the Baltic Sea-North Sea transition. Ophelia, v. 31, p.51-72, 1989. https://doi.org/ 10.1080/00785326.1989.10430849

Kerner, M. Coupling of microbial fermentation and respiration processes in an intertidal mudflat of the Elbe Estuary. Limnology and Oceanography, v. 38, p. 314-330, 1993. https://doi.org/10.4319/ lo.1993.38.2.0314 
Klump, J. V.; Martens, C. S. Benthic nitrogen regeneration. In: Carpenter, E. J.; Capone, D. G. (Ed.). Nitrogen in marine environments. New York: Academic Press, 1983. p. 411-457.

La Roche, J. Ammonium regeneration: Its contribution to phytoplankton nitrogen requirements in a eutrophic environment. Marine Biology, v. 75, p. 231-240, 1983. https://doi.org/10.1007/BF00406007

Lohse, L.; Malschaert, J. F. P.; Slomp, C. P.; Helder, W.; van Raaphorst, W. Nitrogen cycling in North Sea sediments: Interaction of denitrification and nitrification in offshore and coastal areas. Marine Ecology Progress Series, v. 101, p. 283-296, 1993.

Lomstein, B.; Blackburn, T. H. Sediment nitrogen cycling in Aarhus Bay, Denmark. Copenhagen: Miljoministeriet, 1992.

Mukherjee, A.; Das, S.; Chakraborty, S.; De, T. K. An ex situ and in vitro approach to delineate pennate diatom species with bioindicator potentials in a well mixed tropical estuarine ecosystem. Brazilian Journal of Biological Sciences, v. 3, no. 6, p. 299-317, 2016. http://doi.org/10.21472/ bjbs.030607
Paerl, H. W.; Crocker, K. M.; Prufert, L. E. Limitation of $\mathrm{N}_{2}$ fixation in coastal marine waters: Relative importance of molybdenum, iron, phosphorus and organic matter availability. Limnology and Oceanography, v. 32, p.525-536, 1987 . https://doi.org/ 10.4319/lo.1987.32.3.0525

Sloth, N. P.; Blackburn H.; Hansen L. S.; Risgaard-Petersen, N.; Lomstein, B. A. Nitrogen cycling in sediment with different organic loading. Marine Ecology Progress Series, v. 116, p. 163-170, 1995.

Smith, S. V.; Hollibraugh, J. T. Carboncontrolled nitrogen cycling in a marine 'macrocosm': An ecological scale model for managing cultural eutrophication. Marine Ecology Progress Series, v. 52, p. 103-109, 1989.

Sørensen, J.; Jørgensen, B. B.; Revsbech, N. P. A comparison of oxygen, nitrate and sulfate respiration in coastal marine sediments. Microbial Ecology, v. 5, p. 105-115, 1979. https://doi.org/10.1007/BF02010501 